\title{
Rapid Sequence Induction on trauma patients performed by a rural and suburban air ambulance service: a 16-month audit of practice
}

\author{
A Chesters ${ }^{*}$, N Keefe, J Mauger \\ From London Trauma Conference 2012 \\ London, UK. 4-7 December 2012
}

\section{Introduction}

This poster describes the first 16 months experience of pre-hospital RSI in a rural and sub-urban helicopter-based doctor-paramedic service after the introduction of a standard operating procedure already proven in an urban trauma environment.

\section{Method}

A retrospective database review of all missions between October 2010 and January 2012 was carried out. Any RSI or intubation carried out on an injured patient was included, regardless of age or indication. Patients who were intubated by Ambulance Service personnel prior to the arrival of the EAAA team were excluded.

\section{Results}

The team was activated 1156 times and attended 763 cases. A total of 69 RSIs occurring within the study period were identified as having been carried out by the EAAA team. There were no failed intubations that required a rescue surgical airway or the placement of a supraglottic airway device. For RTCs, the overall on scene time for patients who required an RSI was 40 minutes (range 15-72 minutes). For all other trauma, the average on scene time was 48 minutes (range 25-77 minutes).

\section{Conclusion}

We have demonstrated the successful introduction of a pre-hospital care standard operating procedure, already tested in the urban trauma environment, to a rural and suburban air ambulance service operating a full-time doctor-paramedic model. We have shown a zero failed intubation rate over 16 months of practice during which

East Anglian Air Ambulance, UK time over 750 missions were flown with $11.5 \%$ of these resulting in an RSI.

Published: 28 May 2013

doi:10.1186/1757-7241-21-S1-S1

Cite this article as: Chesters et al.: Rapid Sequence Induction on trauma patients performed by a rural and suburban air ambulance service: a 16-month audit of practice. Scandinavian Journal of Trauma, Resuscitation and Emergency Medicine 2013 21(Suppl 1):S11.
Submit your next manuscript to BioMed Central and take full advantage of:

- Convenient online submission

- Thorough peer review

- No space constraints or color figure charges

- Immediate publication on acceptance

- Inclusion in PubMed, CAS, Scopus and Google Scholar

- Research which is freely available for redistribution
() Biomed Central

\section{(Ciomed Central}

(c) 2013 Chesters et al; licensee BioMed Central Ltd. This is an Open Access article distributed under the terms of the Creative Commons Attribution License (http://creativecommons.org/licenses/by/2.0), which permits unrestricted use, distribution, and reproduction in any medium, provided the original work is properly cited. 